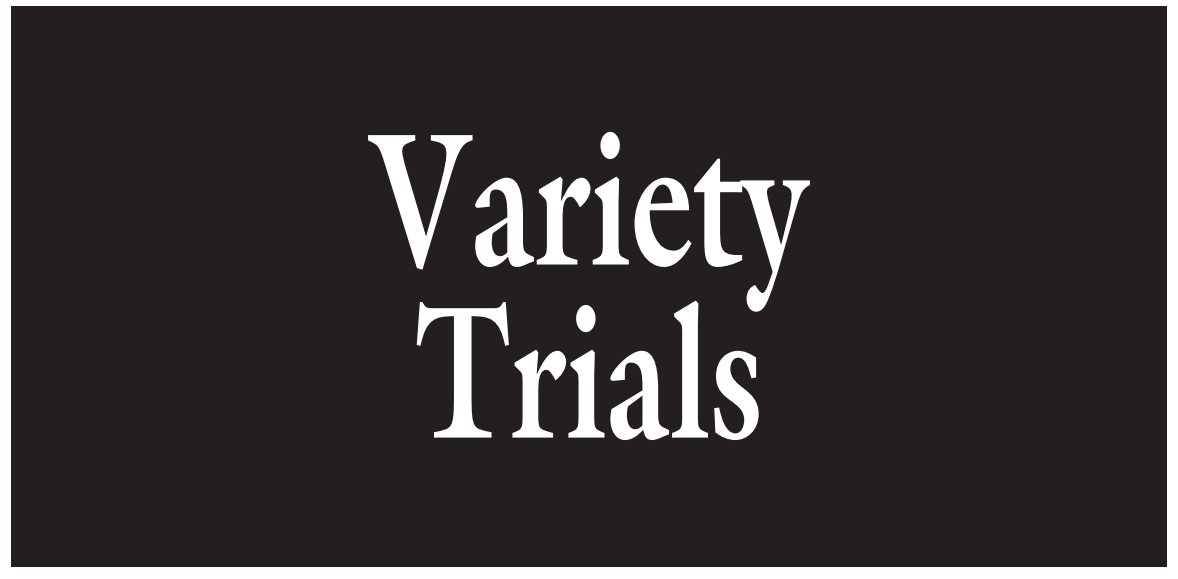

\section{Yield and Fruit Quality Traits of Mamey Sapote Cultivars Grown at Two Locations in Puerto Rico}

\author{
Ricardo Goenaga ${ }^{1}$ and David Jenkins
}

\begin{abstract}
AdDitional InDEX wORDs. soluble solids concentration, Pouteria sapota
SumMARY. The demand for tropical fruits has increased significantly during the last decade as consumers seek healthy and more diverse food products. There is a lack of formal experimentation to determine yield performance and fruit quality traits of mamey sapote (Pouteria sapota) cultivars. Six mamey sapote cultivars (Copan, Magaña, Mayapan, Pace, Pantin, Tazumal) grown on Ultisol and Oxisol soils were evaluated for 5 years at Corozal and Isabela, PR, respectively. There was a significant difference in the number and weight of fruit per hectare between locations, averaging 25,929 fruit/ha and $16,527 \mathrm{~kg} \cdot \mathrm{ha}^{-1}$ at Corozal and 17,887 fruit/ha and $11,920 \mathrm{~kg} \cdot \mathrm{ha}^{-1}$ at Isabela. 'Tazumal' had the highest 5 -year mean number and weight of fruit per hectare, but fruit of this cultivar was very small and contained several seeds, which could reduce its marketability. At Corozal, cultivars Tazumal and Magaña had significantly higher fruit yield per hectare than the rest of the cultivars, whereas 'Magaña', 'Tazumal', and 'Pantín' had the highest fruit yield at Isabela. At both locations, 'Pantin' had relatively high yield, above-average soluble solids concentration values, and adequate fruit size and weight for domestic and export markets (650-900 g), making this cultivar suitable for planting at various agroenvironments typical of the humid tropics.
\end{abstract}

$\mathrm{T}$ he demand for tropical fruits has increased more than $40 \%$ during the last decade [Food and Agriculture Organization of the United Nations (FAO), 2010] as consumers seek healthy and more diverse food products. Mamey sapote is native

Tropical Agriculture Research Station, USDA-ARS, 2200 P.A. Campos Avenue, Suite 201, Mayaguez, PR 00680-5470

We thank Nicolas Díaz (deceased), Angel Marrero, Jose Luis Rodríguez, Edmundo Rivera, Tomás Miranda, and Pablo Ríos for their excellent field assistance.

Mention of trade names or commercial products in this publication is solely for the purpose of providing specific information and does not imply recommendation or endorsement of the U.S. Department of Agriculture.

${ }^{1}$ Corresponding author. E-mail: Ricardo.Goenaga@ ars.usda.gov. to Mexico and Central American countries as far south as northern Nicaragua (Balerdi and Shaw, 1998; Morton, 1987; Mossler and Crane, 2009). It is also cultivated in the Caribbean,
Florida, and other tropical and subtropical regions of the world (Téllez et al., 2009). The tree thrives from sea level to $900 \mathrm{~m}$ in elevation and under an annual rainfall of $\approx 2000 \mathrm{~mm}$. It adapts to a wide range of soil types including sandy or heavy soils; however, it does not withstand dry periods or waterlogged soils (Almeyda and Martin, 1976; Morton, 1987). Depending on the cultivar, fruit shape varies from round to elliptical; it has a leathery brown skin and contains one to three large seeds. Fruit pulp is sweet, soft, and orange or deep red in color when ripe, and it is consumed fresh or processed to prepare ice cream or milkshakes. The fruit is high in vitamins A and $\mathrm{E}$, minerals, and carotenoid content [Alia-Tejacal et al., 2007; U.S. Department of Agriculture (USDA), 2011]. The fruit has been shown not to be a host to the caribbean fruit fly [Anastrepha suspensa (Gould and Hallman, 2001)] or the west indian fruit fly [Anastrepha obliqua (Jenkins and Goenaga, 2007)], making its export possible to sites where these fruit flies are not present.

There is little information available on total production area of mamey sapote worldwide. Mexico is probably the largest producer with an estimated production of $16,000 \mathrm{Mg}$ (Téllez et al., 2009), although small orchards are reportedly established in Spain, the Philippines, Vietnam, Australia, and India (Balerdi and Shaw, 1998). Florida and Puerto Rico are the only production areas in the United States with $\approx 140$ ha (Mossler and Crane, 2009; Y. Aron, personal communication).

Commonly used cultivars for commercial production include Copan, Magaña, Andres-2, and Pantin (Balerdi and Shaw, 1998; Mossler and Crane, 2009). Production of fully mature trees of these cultivars is estimated to range from 200 to 500 fruit per year (Mossler

\begin{tabular}{llll}
\hline $\begin{array}{l}\text { Units } \\
\text { To convert U.S. to SI, } \\
\text { multiply by }\end{array}$ & U.S. unit & SI unit & $\begin{array}{l}\text { To convert SI to U.S., } \\
\text { multiply by }\end{array}$ \\
\hline 0.4047 & $\mathrm{acre}(\mathrm{s})$ & $\mathrm{ha}$ & 2.4711 \\
0.3048 & $\mathrm{ft}$ & $\mathrm{m}$ & 3.2808 \\
3.7854 & gal & $\mathrm{L}$ & 0.2642 \\
2.54 & inch(es) & $\mathrm{cm}$ & 0.3937 \\
25.4 & inch(es) & $\mathrm{mm}$ & 0.0394 \\
1.1209 & $\mathrm{lb} / \mathrm{acre}$ & $\mathrm{kg} \cdot \mathrm{ha}^{-1}$ & 0.8922 \\
28.3495 & $\mathrm{oz}$ & $\mathrm{g}$ & 0.0353 \\
1 & $\mathrm{ppm}$ & $\mathrm{mg} \cdot \mathrm{kg}^{-1}$ & 1 \\
6.8948 & $\mathrm{psi}$ & $\mathrm{kPa}$ & 0.1450 \\
0.9072 & ton $(\mathrm{s})$ & $\mathrm{Mg}$ & 1.1023 \\
$\left({ }^{\circ} \mathrm{F}-32\right) \div 1.8$ & ${ }^{\circ} \mathrm{F}$ & ${ }^{\circ} \mathrm{C}$ & $\left(1.8 \times{ }^{\circ} \mathrm{C}\right)+32$
\end{tabular}


and Crane, 2009). However, replicated field trials to evaluate these and other mamey sapote cultivars have been very limited. Further, very little is known on the agroenvironmental conditions and other factors that may limit productivity of mamey sapote (FAO, 1995). The objective of this study was to evaluate yield performance and fruit quality traits of six mamey sapote cultivars grown in two distinct agroenvironments.

\section{Materials and methods}

This study was conducted in Puerto Rico at the USDA, Agricultural Research Service Research Farm in Isabela (Coto clay: clayey, kaolinitic isohyperthermic Typic Hapludox) and at the Corozal Agricultural Experiment Station of the University of Puerto Rico (Corozal clay: clayey, mixed, isohyperthermic Aquic Haplohumults). Soil and climatic characteristics are described in Tables 1 and 2. Soil samples from each site were taken $\approx 2$ months before planting by taking 15 borings at a depth of $0-25 \mathrm{~cm}$ from each of the 10 projected cultivar rows. Samples were air-dried and passed through a 20-mesh screen. Soil pH in water and $0.01 \mathrm{~m}$ calcium chloride ( 1 soil : 2 water) were measured with a glass electrode. Exchangeable cations (potassium, magnesium, calcium) were extracted with neutral $\mathrm{l} \mathrm{N}$ ammonium acetate and determined by atomic absorption spectroscopy (Sumner and Miller, 2007). Phosphorus was extracted with $1 \mathrm{~N}$ ammonium fluoride and $0.5 \mathrm{~N}$ hydrochloric acid and determined using the ascorbic acid method (Benton, 2001). Organic carbon was determined by the WalkleyBlack method (Nelson and Sommers, 2007). Soil ammonium and nitrate were determined by steam distillation (Mulvaney, 2007).

Six-month-old trees of cultivars Copan, Magaña, Mayapan, Pace, Pantin, and Tazumal grafted onto 'Pantin' seedling rootstocks were transplanted to the field on $2 \mathrm{Feb} .2000$ (Isabela) and on 25 Apr. 2000 (Corozal) and were arranged in a randomized complete block design with five replications at each location. Before transplanting, the soil was chisel-plowed to a depth of $\approx 90 \mathrm{~cm}$. Planting holes of $\approx 1.5-\mathrm{ft}$ deep were dug with an auger connected by a drive shaft to the power-take-off unit of a tractor. On transplanting, each plant received $11 \mathrm{~g}$ granular phosphorus provided in the form of triple superphospate. Within a replication, plots for each cultivar contained three trees spaced $20 \mathrm{ft}$ apart and $20 \mathrm{ft}$ between adjacent rows in a triangular array, $\approx 108$ trees per acre. The experiments were surrounded by two guard rows of 'Tazumal' seedlings. Irrigation based on tensiometer readings was provided with spinner jets (model DXMAG368X; Maxijet, Dundee, FL) spaced $20 \mathrm{ft}$ apart and providing $13.5 \mathrm{gal} / \mathrm{h}$ at $20 \mathrm{psi}$ when the soil water tension at a depth of 30 $\mathrm{cm}$ exceeded $50 \mathrm{kPa}$. Fertilization was provided every 3 months using a $15 \mathrm{~N}-$ $2.2 \mathrm{P}-16.3 \mathrm{~K}-1.8 \mathrm{Mg}$ fertilizer at a rate of 100,200 , and $269 \mathrm{~kg} \cdot \mathrm{ha}^{-1}$ in 2002 , 2006, and 2009, respectively. Herbicide (glyphosate) for weed control was applied only in strips within the planting row. Weeds between rows were controlled with a tractor mower.

Harvests were initiated in Jan. 2005 at both locations. At this time, grafted trees were $\approx 6.5$-years old and producing fruit in sufficiently large numbers for commercial harvest and sale. At each harvest, number and weight of marketable fruit were recorded and weighed. Fruits were harvested at color break when they started to show a pink rather than green tissue upon light scratching of the fruit skin. Representative fruit from each cultivar is shown in Fig. 1.
Fruit totaling $10 \%$ of those harvested were used to determine fruit length and diameter. Readings of total soluble solids were also recorded with a temperature-compensated digital refractometer (Pal-I; ATAGO Co., Tokyo, Japan) when the fruit ripened, $\approx 5$ to $7 \mathrm{~d}$ after harvest.

Analysis of variance was carried out using the GLM procedure of SAS (release 9.1 for Windows; SAS Institute, Cary, NC). After significant $\mathrm{F}$ test at $P \leq 0.05$, mean separation was performed with the least significant difference test.

\section{Results and discussion}

Year, location, and cultivars showed significant effects $(P \leq 0.05)$ on all fruit parameters measured in the study. The only exception was fruit total soluble solids, which did not show a significant location effect. The year $\times$ location interaction was significant for total number of fruit, fruit yield, fruit length, and fruit soluble solids but not for fruit diameter and individual fruit weight (Table 3). Except for fruit diameter, the year $\times$ cultivar interaction was also significant for most fruit variables.

At both locations, only cultivars Magaña and Tazumal exhibited an overall increase in the number of fruit

Table 1. Average preplant soil characteristics at two mamey sapote test sites in Puerto Rico measured to a depth of $25 \mathrm{~cm}$ (9.8 inches).

\begin{tabular}{lcr}
\hline & \multicolumn{2}{c}{ Location } \\
\cline { 2 - 3 } Soil characteristic & Corozal (Ultisol) & Isabela (Oxisol) \\
\hline $\mathrm{pH}$ in water & 4.75 & 6.62 \\
$\mathrm{pH}$ in calcium chloride & 4.11 & 6.06 \\
Ammonium nitrogen $\left(\mathrm{mg} \cdot \mathrm{kg}^{-1}\right)$ & 23.01 & 11.05 \\
Nitrate nitrogen $\left(\mathrm{mg} \cdot \mathrm{kg}^{-1}\right)$ & 9.17 & 6.60 \\
Organic carbon $(\%)$ & 1.19 & 1.20 \\
Phosphorous $\left(\mathrm{mg}^{\mathrm{z}} \mathrm{kg}^{-1}\right)$ & 5.88 & 15.79 \\
Potassium $\left(\mathrm{mg} \cdot \mathrm{kg}^{-1}\right)$ & 54.00 & 470.00 \\
Calcium $\left(\mathrm{mg} \cdot \mathrm{kg}^{-1}\right)$ & 1551.00 & 1664.00 \\
Magnesium $\left(\mathrm{mg}^{-1} \cdot \mathrm{kg}^{-1}\right)$ & 62.00 & 68.00 \\
\hline
\end{tabular}

${ }^{2} 1 \mathrm{mg} \cdot \mathrm{kg}^{-1}=1 \mathrm{ppm}$.

Table 2. Weather data at two mamey sapote test sites in Puerto Rico (2005-09).

\begin{tabular}{lcc}
\hline & \multicolumn{2}{c}{ Location } \\
\cline { 2 - 3 } Site characteristic & Corozal (Ultisol) & Isabela (Oxisol) \\
\hline Total rainfall $(\mathrm{cm})$ & 964 & 890 \\
Total evaporation $(\mathrm{cm})$ & 696 & 808 \\
Maximum temperature $\left({ }^{\circ} \mathrm{C}\right)$ & 30.6 & 29.3 \\
Minimum temperature $\left({ }^{\circ} \mathrm{C}\right)$ & 19.9 & 21.8 \\
Elevation $(\mathrm{m})$ & 195 & 126 \\
\hline
\end{tabular}

${ }^{\mathrm{z}} 1 \mathrm{~cm}=0.3937$ inch, $\left(1.8 \times{ }^{\circ} \mathrm{C}\right)+32={ }^{\circ} \mathrm{F}, 1 \mathrm{~m}=3.2808 \mathrm{ft}$. 
and fruit yield as expected as the trees advance in age (Table 4). The rest of the cultivars exhibited erratic production patterns, which were characterized by relatively low production during
1 or 2 successive years following heavy cropping (Table 4). For example, number of fruit and fruit yield in cultivar Copan declined by $63 \%$ from 2005 to 2006 at Corozal, increased in 2007 and

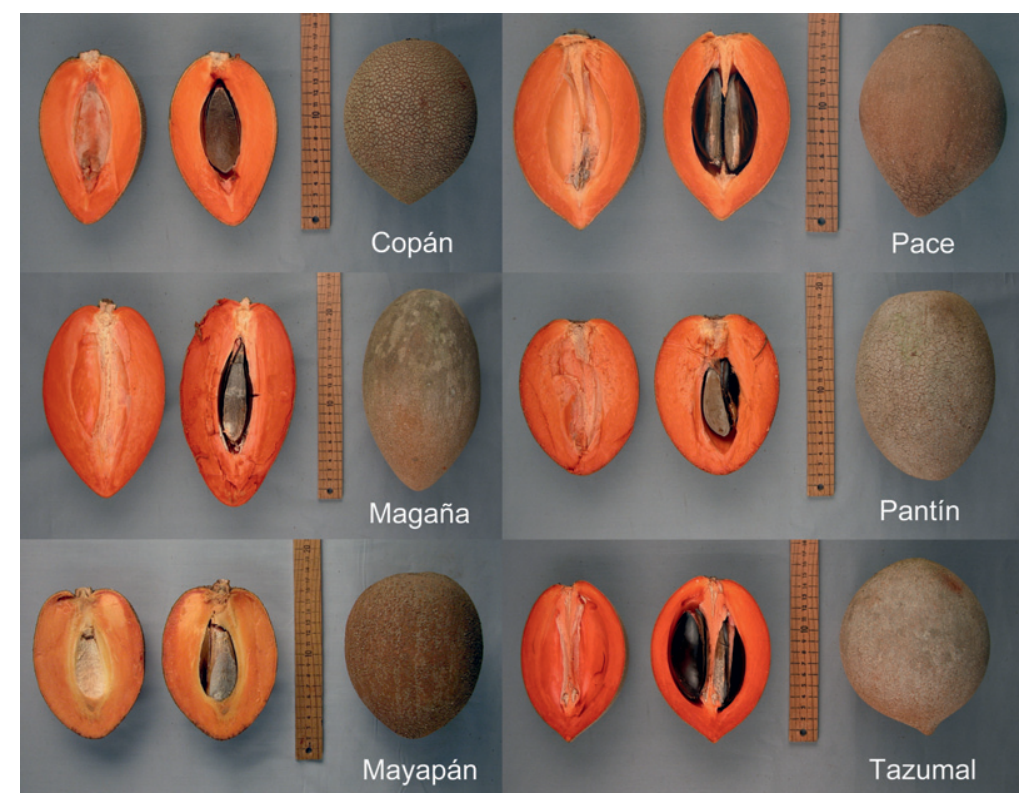

Fig. 1. Representative fruit of six mamey sapote cultivars grown at two locations in Puerto Rico.

2008, and declined again in 2009 by almost $30 \%$. Cultivar Pace showed a drastic decline in fruit production in 2006 at Corozal and in 2008 at Isabela following years of heavy cropping. The possibility of water stress impeding flower initiation or development is ruled out because supplemental irrigation was supplied when necessary. Retention of mature fruit on trees is sometimes practiced [e.g., avocado (Persea americana)] to obtain better market prices. However, this practice can drive the tree into a biennial cropping cycle (Schaffer and Andersen, 1994). In this experiment, fruit were harvested periodically and was not a factor in inducing biennial cropping. Most probably, the high fruit load in some cultivars during 1 or 2 years resulted in depletion of assimilates, which then caused an "off-year" because of light blooming as trees built up carbohydrate reserves (Scholefield et al., 1985). Biennial production is not always characterized by an everyother-year cycle. An "on-year" can be followed by one or more "off-years" and vice versa (Paz-Vega, 1997). The magnitude of this response

Table 3. Yield and fruit quality traits of six mamey sapote cultivars planted at two locations in Puerto Rico. Values are means of five replications and 5 years (2005-09).

\begin{tabular}{|c|c|c|c|c|c|c|c|}
\hline Location & Cultivar & $\begin{array}{c}\begin{array}{c}\text { Fruit } \\
(\text { no. } / \text { ha })^{\mathrm{z}}\end{array} \\
\end{array}$ & $\begin{array}{l}\text { Fruit yield } \\
\left(\mathrm{kg} \cdot \mathrm{ha}^{-1}\right)^{\mathrm{z}}\end{array}$ & $\begin{array}{c}\text { Individual } \\
\text { fruit wt }(\mathrm{g})^{\mathrm{z}}\end{array}$ & $\begin{array}{l}\text { Fruit length } \\
(\mathrm{cm})^{\mathrm{z}}\end{array}$ & $\begin{array}{c}\text { Fruit } \\
\operatorname{diam}(\mathrm{cm})\end{array}$ & $\begin{array}{c}\text { Total soluble } \\
\text { solids }(\%) \\
\end{array}$ \\
\hline \multirow[t]{6}{*}{ Corozal } & Copan & 23,087 & 12,522 & 542 & 13.3 & 9.5 & 29.8 \\
\hline & Magaña & 19,357 & 19,753 & 1,030 & 17.1 & 11.1 & 29.4 \\
\hline & Mayapan & 22,101 & 14,061 & 636 & 13.9 & 10.0 & 30.2 \\
\hline & Pace & 21,588 & 13,007 & 602 & 14.5 & 9.4 & 30.1 \\
\hline & Pantín & 20,825 & 15,337 & 736 & 13.3 & 10.5 & 30.3 \\
\hline & $\operatorname{HSD}(0.05)^{\mathrm{y}}$ & 6,614 & 5,144 & 86 & 0.71 & 0.43 & 1.0 \\
\hline \multirow[t]{5}{*}{ lsabela } & Copan & 6,762 & 4,120 & 609 & 13.5 & 10.5 & 28.8 \\
\hline & Magaña & 16,854 & 17,604 & 1,044 & 18.1 & 12.1 & 28.8 \\
\hline & Mayapan & 8,816 & 6,403 & 726 & 14.6 & 11.1 & 28.9 \\
\hline & Pace & 15,361 & 9,363 & 609 & 14.3 & 9.7 & 30.4 \\
\hline & Pantin & 19,472 & 16,432 & 844 & 14.1 & 11.3 & 31.3 \\
\hline Year $(Y)^{x}$ & & $* * *$ & $* * *$ & $* * *$ & ** & $* * *$ & $* * *$ \\
\hline Location (L) & & $* * *$ & $* * *$ & ** & * & $* * *$ & NS \\
\hline $\mathrm{Y} \times \mathrm{L}$ & & $* * *$ & ** & NS & * & NS & * \\
\hline Cultivar (C) & & $* * *$ & $* * *$ & $* * *$ & $* * *$ & $* * *$ & $* * *$ \\
\hline $\mathrm{L} \times \mathrm{C}$ & & $* * *$ & $* * *$ & $* * *$ & $* * *$ & $* * *$ & $* * *$ \\
\hline $\mathrm{Y} \times \mathrm{C}$ & & $* * *$ & $* * *$ & ** & * & NS & $* * *$ \\
\hline $\mathrm{Y} \times \mathrm{L} \times \mathrm{C}$ & & $* *$ & ** & * & NS & NS & $* * *$ \\
\hline
\end{tabular}

${ }^{\mathrm{z}} \mathrm{l}$ fruit $/ \mathrm{ha}=0.4047$ fruit $/$ acre, $\mathrm{l} \mathrm{kg} \cdot \mathrm{ha}^{-1}=0.8922 \mathrm{lb} /$ acre, $\mathrm{l} \mathrm{cm}=0.3937 \mathrm{inch}, \mathrm{l} \mathrm{g}=0.0353 \mathrm{oz}$.

y'Tukey's Studentized range test at $P=0.05$.

${ }_{\mathrm{NS}}{ }^{*},{ }^{* *},{ }^{* *}$ not significant or significant at $P \leq 0.05,0.01$, or 0.001 , respectively, based on analysis of variance. 
varied among cultivars and locations as evidenced by the significant year $\times$ cultivar and location $\times$ cultivar interactions (Table 3 ). In Corozal, 'Tazumal' exhibited an increase in number of fruit and yield throughout the duration of the experiment and leveled off in 2009 (Table 4). A similar response was observed at Isabela except that fruit number and yield declined slightly, but not significantly, in 2007 (Table 4). Similarly, with the exception of 2006 at Corozal and 2005 at Isabela, fruit number and yield of 'Magaña' also increased throughout the duration of the experiment, peaking in 2009 at both locations (Table 4).

At Corozal and Isabela, 'Tazumal' had the highest 5-year mean for number of fruit produced (Table 4). However, it is noteworthy that higher number of fruit in this cultivar did not necessarily translate to significantly higher fruit yield. For example, while 'Tazumal' produced a significantly higher number of fruit than other cultivars at both locations, fruit yield in this cultivar was not significantly different from that of 'Magaña' and 'Pantin' in Isabela. (Table 3). An explanation for this response is the fact that, although 'Tazumal' produced a greater number of fruit, individual fruit weight in this cultivar was significantly lower than that in the rest of the cultivars (Table 3 ). At Corozal, cultivars Tazumal and Magaña had significantly higher fruit yield per hectare than the rest of the cultivars, whereas at Isabela, 'Magaña', 'Tazumal', and 'Pantin' had the highest fruit yield (Table 3 ). At both locations, yield of fruit was significantly lower in 'Copan', but it did not differ significantly from 'Mayapan' at Isabela and from 'Pantin', 'Mayapan', and 'Pace' at Corozal. Cultivars Pace, Mayapan, and Pantin had significantly higher concentration of soluble solids at Isabela, whereas there were no significant differences among cultivars for this variable at Corozal.

Total number and yield of fruit were significantly different between locations, with more fruit produced in Corozal $(25,929$ fruit/ha) than at Isabela (17,887 fruit/ha) (Table 3). Although average fruit number and yield were significantly lower at Isabela, this response was mainly associated with drastic declines in cultivars Copan and Mayapan. These cultivars showed an average reduction in fruit number of $65 \%$ and in fruit yield of $60 \%$ when compared with values in Corozal (Table 3). A possible explanation for why more fruit were produced at Corozal than at Isabela may be that this site is less windy than Isabela. Windy conditions have been reported to be detrimental to some tropical fruit crops (Crane, 2005; Galan-Sauco et al., 1993; Marler et al., 1994), but the effect of wind on physiological processes of mamey sapote is unknown. The possibility that tree nutrition was more favorable for fruit production at Corozal than at Isabela cannot be ruled out even though the source and rate of fertilizer was the same at both locations. Results of nutrient analysis of leaf tissue taken in 2007 showed higher concentration of phosphorus, potassium, and iron at Corozal, whereas nitrogen, calcium, magnesium, and manganese were higher at Isabela (data not shown). Yet, although critical concentrations of nutrients are not reported in the literature for mamey sapote, the leaf nutrient concentration for the above nutrients is within optimal values for many tropical fruit and nut crops (Mills and Jones, 1996). In contrast to 'Copan' and 'Mayapan', the number of fruit and yield in 'Pantin' were similar at both locations, which may indicate that this cultivar is more adaptable to diverse agroenvironmental conditions. Average fruit length and diameter were significantly greater at Isabela than those at Corozal, whereas average soluble solids concentration did not differ significantly between locations (Table 3 ).

Average individual fruit weight was significantly higher at Isabela than that at Corozal (Table 3). At both sites, individual fruit weight of 'Magaña' was significantly higher than the rest of the cultivars, averaging $1047.5 \mathrm{~g}$.

Table 4. Number of fruit and fruit yield of six mamey sapote cultivars grown at two locations in Puerto Rico. Values are means of five replications.

\begin{tabular}{|c|c|c|c|c|c|c|c|c|c|c|c|c|}
\hline \multirow[b]{3}{*}{ Cultivar } & \multicolumn{12}{|c|}{ Location } \\
\hline & \multicolumn{6}{|c|}{ Corozal } & \multicolumn{6}{|c|}{ Isabela } \\
\hline & $5-y r$ & 2005 & 2006 & 2007 & 2008 & 2009 & $5-y r$ & 2005 & 2006 & 2007 & 2008 & 2009 \\
\hline Copan & 23,087 & 17,862 & 6,564 & 23,582 & 39,292 & 28,137 & 6,752 & 2,887 & 6,501 & 7,281 & 11,172 & 5,918 \\
\hline Magaña & 9,357 & 22,166 & 9,751 & 13,593 & 22,201 & 27,151 & 16,854 & 6,689 & 18,292 & 17,826 & 19,458 & 22,004 \\
\hline Mayapan & 22,101 & 13,199 & 11,585 & 11,208 & 46,178 & 28,335 & 8,816 & 3,443 & 12,284 & 4,304 & 20,480 & 3,569 \\
\hline Tazumal & 48,617 & 27,528 & 44,672 & 51,666 & 61,296 & 57,925 & 40,059 & 33,374 & 40,762 & 36,781 & 39,292 & 50,087 \\
\hline \multirow[t]{2}{*}{ HSD $(0.05)^{y}$} & 6,614 & 8,452 & 8,563 & 13,137 & 24,920 & 17,940 & 6,390 & 12,319 & 21,151 & 8,682 & 18,222 & 14,534 \\
\hline & \multicolumn{12}{|c|}{ Fruit yield $\left(\mathrm{kg} \cdot \mathrm{ba} \mathrm{a}^{-1}\right)^{z}$} \\
\hline Copan & 12,510 & 10,033 & 4,614 & 13,766 & 29 & 15,667 & 4,132 & 1,918 & 4,396 & 4,538 & 6,413 & 3,393 \\
\hline Tazumal & 24,485 & 14,486 & 22,541 & 27,206 & 31,142 & 27,049 & 17,596 & 15,109 & 16,401 & 14,765 & 18,362 & 23,345 \\
\hline HSD $(0.05)^{y}$ & 5,144 & 6,601 & 6,383 & 11,219 & NS & NS & 3,780 & 7,433 & 11,519 & 6,936 & 10,910 & 8,294 \\
\hline
\end{tabular}

${ }^{2} 1$ fruit $/ \mathrm{ha}=0.4047$ fruit $/$ acre, $1 \mathrm{~kg} \cdot \mathrm{ha}^{-1}=0.8922 \mathrm{lb} /$ acre .

yukey's Studentized range test at $P=0.05 ;$ NS $=$ not significant. 
Higher individual fruit weight in 'Magaña' was the result of significantly higher length and diameter of fruit (Table 3). At both locations, individual fruit weight was significantly lower in 'Tazumal', but it did not differ significantly from 'Copan' at Corozal. It is noteworthy that fruit of 'Tazumal' were not only smaller (Table 3 ) but also contained between two to four large seeds rendering the edible fraction of the fruit to be significantly less than that in other cultivars. The seed fraction in fruit of this cultivar accounted for $16.5 \%$ of the total fruit weight. In 'Magaña', this was only $5.9 \%$, whereas it was $8.9 \%, 9.5 \%, 11.1 \%$, and $11.2 \%$ in 'Pantin', 'Mayapan', 'Pace', and 'Copan', respectively (data not shown). The small fruit size and large seed number in fruit of 'Tazumal' considerably reduce the marketability potential of this cultivar, which usually requires fruit weighing between 650 and $900 \mathrm{~g}$. Values for individual fruit weight reported in this study for each cultivar fall within the range of those obtained in Florida (Balerdi et al., 2008).

In conclusion, six mamey sapote cultivars were evaluated for the first time at two locations during 5 years of production. These cultivars had significantly higher number of fruit and yield at Corozal (Ultisol) than at Isabela (Oxisol). Cultivar Magaña showed high yield at both locations, but its largesized fruit may make it difficult to market but may be suitable for the processing industry. 'Tazumal' was the highest yielder at both locations, but fruit were the smallest and had several seeds. At both locations, cultivar Pantin had high production of fruit, relatively high yield, and aboveaverage soluble solids concentration values, making this cultivar suitable for planting at various agroenvironments typical of the humid tropics. However, it should be noted that 2 years after completion of this study (11 years after field transplanting), trees in Corozal started to exhibit a high incidence of root rot incited by Phytophthorasp. ( $\approx 30 \%$ tree mortality) possibly brought about by a combination of unusually high rainfall and poor drainage characteristic of heavy-clay Ultisol soils. This long-term factor must be taken into consideration when establishing new plantings of mamey sapote. Efforts to control this disease through trunk injections of fungicide (fosetyl-aluminum) have been unsuccessful. There has been no mortality of trees in Isabela because of this disease. Efforts are being initiated to screen mamey sapote accessions from the USDA germplasm collection in Mayaguez, PR, to identify materials with phytophthora root rot resistance for use as rootstocks.

\section{Literature cited}

Alia-Tejacal, I., R.B. Villanueva-Arce, C. Pelayo-Zaldívar, M.T. Colinas-León, V. López-Martínez, and S. Bautista-Baños. 2007. Postharvest physiology and technology of sapote mamey fruit (Pouteria sapota (Jacq.) H.E. Moore \& Stearn). Postharvest Biol. Technol. 45:285-297.

Almeyda, N. and F.W. Martin. 1976. Cultivation of neglected tropical fruits with promise. Part 2 . The mamey sapote. U.S. Dept. Agr. Publ. ARS-S-156.

Balerdi, C.F., J.H. Crane, and I. Maguire. 2008. Mamey sapote growing in the Florida home landscape. Univ. of Florida, Florida Coop. Ext. Serv., Inst. Food Agr. Sci., Publ. FC-30.

Balerdi, C.F. and P.E. Shaw. 1998. Sapodilla, sapota and related fruit, p. 78-136. In: P.E. Shaw, H.T. Chan, and S. Nagy (eds.). Tropical and subtropical fruits. AgScience, Auburndale, FL.

Benton, J.J. 2001. Laboratory guide for conducting soil tests and plant analysis. CRC Press, Boca Raton, FL.

Crane, J.H. 2005. Carambola growing in the Florida home landscape. Univ. of Florida, Hort. Sci. Dept., Florida Coop. Ext. Serv. Inst. Food Agr. Sci., Fact Sheet HS 12 revised.

Food and Agriculture Organization of the United Nations. 1995. Neglected crops: 1492 From a different perspective. FAO Plant Production and Protection Series, no. 26. FAO, Rome.

Food and Agriculture Organization of the United Nations. 2010. FAOSTAT statistics database 2009. 30 Jan. 2012. <http:// faostat.fao.org/site/567/default.aspx\# ancor>.

Galan-Sauco, V., U.G. Menini, and H.D. Tindall. 1993. Carambola cultivation. FAO Plant Production and Protection paper no. 108. FAO, Rome.

Gould, W.P. and G. Hallman. 2001. Host status of mamey sapote to caribbean fruit fly (Diptera: Tephritidae). Florida Entomol. 84:370-375

Jenkins, D.A. and R. Goenaga. 2007. Host status of mamey sapote, Pouteria sapota (Sapotaceae), to the west indian fruit fly, Anastrepha obliqua (Diptera: Tephritidae) in Puerto Rico. Florida Entomol. 90:384-388.

Marler, T.E., A.P. George, R.J. Nissen, and P.C. Andersen. 1994. Miscellaneous tropical fruits, p. 206-211. In: B. Schaffer and P.C. Andersen (eds.). Handbook of environmental physiology of fruit crops: II. Subtropical and tropical crops. CRC Press, Boca Raton, FL.

Mills, H.A. and B.J. Jones, Jr. 1996. Plant analysis handbook II. Micromacro Publishing, Athens, GA.

Morton, J.F. 1987. Fruits of warm climates. Media Inc., Greensboro, NC

Mossler, M.A. and J.H. Crane. 2009. Florida crop/pest management profile: Mamey sapote and sapodilla. Univ. of Florida, Florida Coop. Ext. Serv., Inst. Food Agr. Sci. Circulation 1414.

Mulvaney, R.L. 2007. Nitrogen: Inorganic forms, p. 1123-1184. In: D.L. Sparks (ed.). Methods of soil analysis. Part 3. Chemical methods. Soil Sci. Soc. Amer., Amer. Soc. Agron., Madison, WI.

Nelson, D.W. and L.E. Sommers. 2007. Total carbon, organic carbon and organic matter, p. 961-1010. In: D.L. Sparks (ed.). Methods of soil analysis. Part 3. Chemical methods. Soil Sci. Soc. Amer., Amer. Soc. Agron., Madison, WI

Paz-Vega, S. 1997. Alternate bearing in the avocado (Persea americana Mill.), p. 117-148. California Avocado Soc. 1997 Yrbk. 81 .

Schaffer, B. and P.C. Andersen. 1994. Miscellaneous tropical fruits, p. 3-37. In: B. Schaffer and P.C. Andersen (eds.). Handbook of environmental physiology of fruit crops: II. Subtropical and tropical crops. CRC Press, Boca Raton, FL.

Scholefield, P.B., M. Sedgley, and D.McE. Alexander. 1985. Carbohydrate cycling in relation to shoot growth, floral initiation and development and yield in the avocado. Sci. Hort. 25:99-110

Sumner, M.E. and W.P. Miller. 2007. Cation exchange capacity and exchange coefficients, p. 1201-1230. In: D.L. Sparks (ed.). Methods of soil analysis. Part 3. Chemical methods. Soil Sci. Soc. Amer., Amer. Soc. Agron. Madison, WI.

Téllez, P.P., V.C. Saucedo, G.M.L. Arévalo, and G.S. Valle. 2009. Ripening of mamey fruits (Pouteria sapota Jacq.) treated with 1 -methylcyclopropene and refrigerated storage. CYTA J. Food 7:45-51.

U.S. Department of Agriculture. 2011. National nutrient database for standard reference. 30 Jan. 2012. <http://www.ars. usda.gov/Services/docs.htm?docid=8964> . 